\title{
Red Blood Cell Distribution Width in Patients with Chronic Obstructive Lung Diseases: Alteration due to Severity of Exacerbation
}

\author{
Sumeyye Alparslan Bekir ${ }^{1}$, Eylem Acaturk ${ }^{2}$, Sinem Gungor ${ }^{2}$, Murat Yalcinsoy ${ }^{3}$, Ozlem \\ Sogukpinar ${ }^{2}$, Baran Gundogus ${ }^{2}$, Emine Aksoy ${ }^{4}$, Meltem Agca ${ }^{2}$, Sinem Agca ${ }^{5}$, Hatice \\ Turker $^{2}$, and Zuhal Karakurt ${ }^{6}$ \\ ${ }^{1}$ University of Health Sciences Sureyyapaşa Chest Diseases and Thoracic Surgery Training \\ and Research Hospita \\ ${ }^{2}$ Health Sciences University Sureyyapasa Pulmonary Disease and Pulmonary Surgery \\ Training and Research Hospital \\ ${ }^{3}$ Inonu University Faculty of Medicine \\ ${ }^{4}$ University of Health Sciences Sureyyapaşa Chest Diseases and Thoracic Surgery \\ Education and Research Hospital \\ ${ }^{5}$ Private Hospital \\ ${ }^{6}$ Sureyyapasa Chest Diseases and Thoracic Surgery Training and Research Hospital
}

June 6, 2021

\begin{abstract}
Background: Elevated red blood cell distribution width (RDW) levels were associated with mortality in patients with stable chronic obstructive lung diseases (COPD). There are limited data about RDW levels in COPD exacerbation. Aim/Objective: The association of the RDW levels with the severity of the acute exacerbation of COPD (AECOPD) were evaluated according to admission location, (outpatient-clinic, ward and intensive care unit (ICU). Methods: Cross sectional retrospective study designed in tertiary chest dieases hospital. COPD patients admitted to hospital outpatiens-clinic, ward and ICU due to AECOPD were included. Patients demographics, RDW, C-reactive protein (CRP), biochemistry values were recorded. RDW values were subdivided below $0.11 \%$ (low), above and equal $0.15 \%$ (high) and between $0.11-0.15 \%$ (normal). Neutrophile to lymphocyte ratio (NLR) and platelet to mean platelet volume (PLT-MPV) were also calculated. Recorded values were compared according to where AECOPD was treated. Results: 2771 COPD patients (33\% female) and 1429 outpatients-clinic, 1156 ward and 186 ICU were enrolled in the study. The median RWD values in outpatients-clinic, ward and ICU were 0.16 (0.09-0.26), $0.07(0.01-0.14)$ and $0.01(0.00-0.07)$ respectively $(\mathrm{p}<0.001)$. In outpatient to ward and ICU, low RDW values were significantly increased $(31 \%, 66 \%, 83 \%$ respectively) and high RDW values significantly decreased $(54 \%, 24 \%, 10 \%)(\mathrm{p}<0.001)$. According to attack severity, low RDW values were determined. Conclusion: Patients with AECOPD, lower RDW values should be considered carefully. Lower RDW can be used for decision of COPD exacerbation severity and follow up treatment response. What is already known about this topic; In current studies, elevated RDW levels were associated with mortality in patients with stable COPD. What does this article add; Currently, there are limited data about RDW levels in COPD exacerbation. In the present study, the association of the RDW levels according to the severity of AECOPD were evaluated due to admission location.
\end{abstract}

\section{Hosted file}

MANUSCRIPT 1.doc available at https://authorea.com/users/418226/articles/525042-red-blood- 
cell-distribution-width-in-patients-with-chronic-obstructive-lung-diseases-alterationdue-to-severity-of-exacerbation

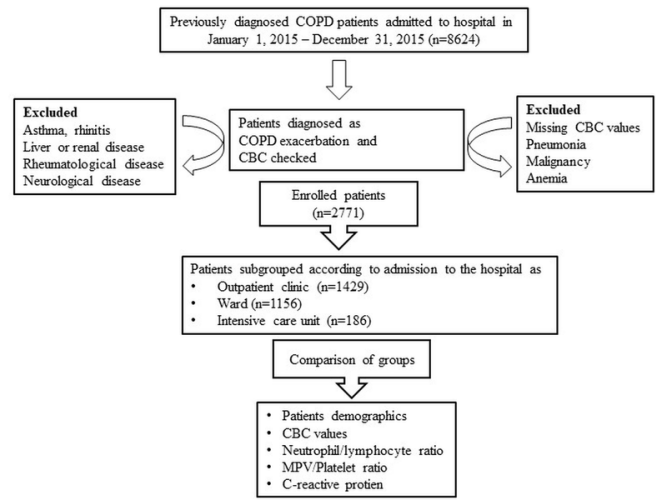

Red blood cell distribution in patients with acute exacerbation of chronic obstructive pulmonary disease

\section{Patients \%}

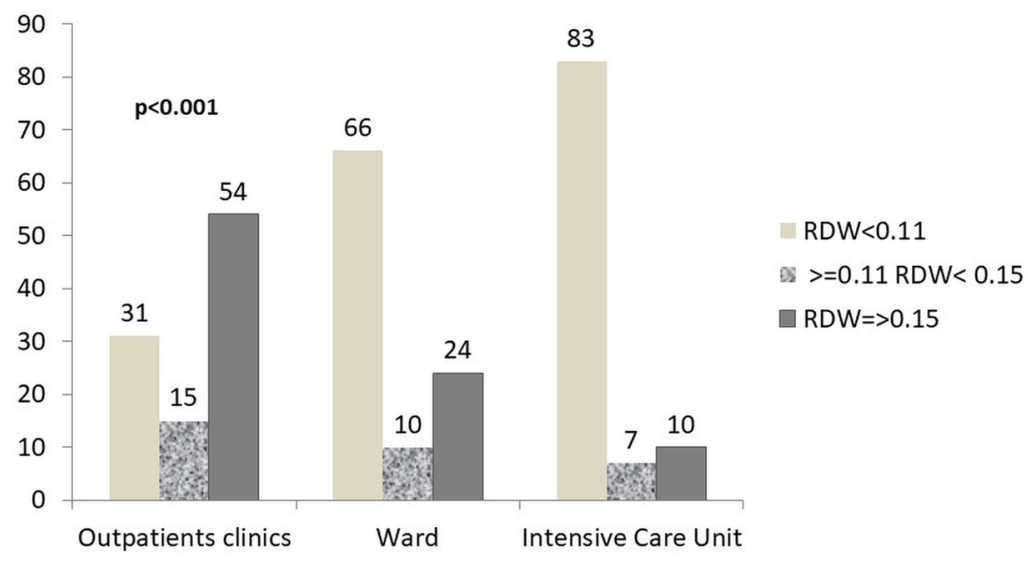

\section{Hosted file}

Table 1.docx available at https://authorea.com/users/418226/articles/525042-red-blood-celldistribution-width-in-patients-with-chronic-obstructive-lung-diseases-alteration-due-toseverity-of-exacerbation

\section{Hosted file}

Table 2.docx available at https://authorea.com/users/418226/articles/525042-red-blood-celldistribution-width-in-patients-with-chronic-obstructive-lung-diseases-alteration-due-toseverity-of-exacerbation 